\title{
Twenty-year advanced DInSAR analysis of severe land subsidence: the Alto Guadalentín Basin (Spain) case study
}

\author{
Roberta Bonì $^{1}{ }^{1}$, Gerardo Herrera ${ }^{2,3,4}$, Claudia Meisina ${ }^{1}$, Davide Notti ${ }^{1,10}$, Marta Béjar- \\ Pizarro $^{2,3}$, Francesco Zucca ${ }^{1}$, Pablo J. González ${ }^{5}$, Mimmo Palano ${ }^{6}$, Roberto Tomás ${ }^{2,7,3}$, José \\ Fernández $^{8}$, José Antonio Fernández-Merodo ${ }^{2,3}$, Joaquín Mulas ${ }^{2,3}$, Ramón Aragón ${ }^{2,3}$, Carolina \\ Guardiola-Albert $^{2}$ and Oscar Mora ${ }^{9}$
}

1 Department of Earth and Environmental Science, University of Pavia, Via Ferrata 1, 27100 Pavia, Italy ; E-Mails: roberta.boni01@unipv.it; claudia.meisina@unipv.it; davidenotti@gmail.com; $\underline{\text { francesco.zucca@unipv.it }}$

2 Geohazards InSAR laboratory and modeling group. Instituto Geológico y Minero de España (IGME), C/. Alenza 1, 28003 Madrid, Spain; E-Mails: g.herrera@igme.es; m.bejar@igme.es; jose.fernandez@igme.es; j.mulas@igme.es; r.aragon@igme.es; c.guardiola@igme.es

${ }^{3}$ Unidad Asociada de investigación IGME-UA de movimientos del terreno mediante interferometría radar (UNIRAD),Universidad de Alicante, P.O. Box 99, 03080 Alicante, Spain

${ }^{4}$ Earth Observation and Geohazards Expert Group (EOEG), EuroGeoSurveys, the Geological Surveys of Europe, 36-38, Rue Joseph II, 1000 Brussels, Belgium

5 Institute of Geophysics and Tectonics. School of Earth and Environment. University of Leeds, Leeds, LS2 9JT, United Kingdom; E-Mail: p.j.gonzalez@leeds.ac.uk

6 Istituto Nazionale di Geofisica e Vulcanologia, Osservatorio Etneo - Sezione di Catania, Piazza Roma 2, 95123 Catania, Italy; E-Mail: mimmo.palano@ingv.it

7 Universidad de Alicante, Dpto. de Ingeniería Civil. Escuela Politécnica Superior de Alicante. P.O. Box 99. 03080 Alicante Spain; E-Mail: roberto.tomas@ua.es 


\author{
8 Instituto de Geociencias (CSIC, UCM), Plaza de Ciencias 3, Ciudad Universitaria, 28040 Madrid, \\ Spain; E-Mail: jft@mat.ucm.es \\ 9 Altamira Information, C/. Còrsega 381-387, 08037 Barcelona, Spain; E-Mail: \\ oscar.mora@altamira-information.com \\ 10 Departamento de Geodinámica, Universidad de Granada, Avenida Fontenueva, Granada, Spain \\ * Author to whom correspondence; E-Mail: roberta.boni01@unipv.it; \\ Tel.: +39 382985831
}

Received: / Accepted: / Published:

\begin{abstract}
A twenty-year period of severe land subsidence evolution in the Alto Guadalentín Basin (southeast Spain) is monitored using multi sensor SAR images, processed by advanced differential interferometric synthetic aperture radar (DInSAR) techniques. The SAR images used in this study consist of four data sets acquired by ERS-1/2, ENVISAT, ALOS and COSMO-SkyMed satellites between 1992 and 2012. The integration of ground surface displacement maps retrieved for different time periods allows us to quantify up to $2.50 \mathrm{~m}$ of cumulated displacements that occurred between 1992 and 2012 in the Alto Guadalentín Basin. DInSAR results were locally compared with global positioning system (GPS) data available for two continuous stations located in the study area, demonstrating the high consistency of local vertical motion measurements between the two different surveying techniques. An average absolute error of $4.6 \pm 4 \mathrm{~mm}$ for the ALOS data and of $4.8 \pm 3.5 \mathrm{~mm}$ for the COSMO-SkyMed data confirmed the reliability of the analysis. The spatial analysis of DInSAR ground surface displacement reveals a direct correlation with the thickness of the compressible alluvial deposits. Detected ground subsidence in the past 20 years is most likely a consequence of a 100-200 m ground water level drop that has persisted since the 1970s due to the overexploitation of the Alto
\end{abstract}


Guadalentín aquifer system. The negative gradient of the pore pressure is responsible for the extremely slow consolidation of a very thick (>100 m) layer of fine-grained silt and clay layers with low vertical hydraulic permeability (approximately $50 \mathrm{~mm} / \mathrm{h}$ ) wherein the maximum settlement has still not been reached.

Keywords: Land subsidence; Persistent Scatterer Interferometry (PSI); Spatio-temporal analysis; Lorca; groundwater level; GPS

\section{Introduction}

Land subsidence triggered by the overexploitation of aquifers represents a common hazard impacting extensive areas worldwide. For instance, well-known examples of pumping-induced subsidence affected the Antelope valley in California (Galloway et al. 1998), the North China Plain (Changming et al. 2001), Bangkok in Thailand (Phien-Wej et al. 2006) and the city of Bologna in Italy (Stramondo et al. 2007). This type of land subsidence causes permanent inundation of land, aggravates flooding, changes topographic gradients and thus causes infrastructure damage, ruptures the land surface, and reduces the capacity of aquifers to store water, posing a risk for the society that can have a sound economic impact (Holzer and Galloway, 2005). For these reasons, mapping and monitoring the areal extent and temporal evolution of this phenomenon are critical. Differential SAR interferometry represents an advanced remote sensing tool capable of mapping displacements over wide areas at a very high spatial resolution and with a lower annual cost per measurement point and per square kilometre than other conventional techniques such as GPS, topographic measure and extensometers (Tomás et al. 2014). According to Sansosti et al. (2010), advanced DInSAR techniques can be grouped into two main categories: persistent scatterer (PS) methods that work on localized targets (Ferretti et al. 2001; Arnaud et al. 2003; Werner et al. 2003; Hooper 2008), and small baseline (SB) methods that use 
spatially distributed targets (Lundgren et al. 2001; Berardino et al. 2002; Mora et al. 2003; Schmidt and Burgmann 2003; Prati et al. 2010). In the past decade, several works have focused on the application of these methods to monitor pumping-induced subsidence and to understand the relationship between changes in pore-fluid pressure and aquifer system compaction (e.g., Hoffmann et al. 2001; Declercq et al. 2005; Herrera et al. 2009). Therefore, more case histories are necessary to improve the characterization of the spatio-temporal responses of aquifer systems to hydro-mechanical stresses and to learn to manage the effects, which can be triggered in geologically similar areas.

A recent study (González and Fernández, 2011a) revealed that the Alto Guadalentín Basin, located in southern Spain, is affected by the highest subsidence rates measured in Europe $(>10 \mathrm{~cm} / \mathrm{yr})$ as a direct consequence of long-term aquifer exploitation. In particular, the authors used ERS and ENVISAT data from 1992 to 2007 to identify a delayed transient nonlinear compaction of the Alto Guadalentín aquifer due to the 1990-1995 drought period. Land subsidence due to groundwater exploitation in this region was also detected by Rigo et al. (2013) through the analysis of ENVISAT data, reaching a maximum velocity value of $7.3 \pm 0.9 \mathrm{~cm} / \mathrm{yr}$ during the period 2004-2005. Recently, González et al. (2012) evaluated the relationship between crust unloading due to groundwater overexploitation and stress change on regional active tectonic faults.

This paper presents several novelties with respect to previous works. Previously published displacement measurements obtained from ERS and ENVISAT satellite SAR images for the period 1992-2007 (González and Fernández, 2011a; Rigo et al., 2013) are extended using advanced DInSAR techniques (Duro et al. 2005) to process ALOS PALSAR (2007-2010) and COSMO-SkyMed (20112012) SAR images. The combination of multi-sensor SAR images with different resolutions allows for a wider monitoring time span of 20 years (1992-2012) over the Alto Guadalentín basin. Additionally, the satellite measurements provide locally comparable results with measurements acquired by two permanent GPS stations located in the study area. Furthermore, new geological and hydrogeological data were collected and analysed in order to assess aquifer system compressibility and ground water 
level changes in the past 50 years. The comparison of these data with advanced DInSAR displacement measurements allows for better spatial and temporal understanding of the governing mechanisms of subsidence due to overexploitation of the Alto Guadalentín aquifer system.

\section{Study area}

The Guadalentín Basin is located in the Murcia Province, southeast Spain. It is filled by NeogeneQuaternary sediments transported by the Guadalentín River along an intramontane depression located in the eastern part of the Baetic Cordillera, which is an ENE-WSW-oriented alpine orogenic belt resulting from the ongoing convergence of the African and Iberian plates (Bourgois et al., 1992; Martínez-Díaz, 2002; Masana et al., 2004; Gràcia et al., 2006; Palano et al., 2013). The Guadalentín is a tributary river of the Segura River and forms the Alto and Bajo Guadalentín sub-basins, where Lorca City developed (with approximately 100,000 inhabitants). The basin is mainly filled by Quaternary alluvial fan systems that overlap with Tertiary deposits that are mainly composed of conglomerate and calcarenite sediments that outcrop at the border of the basin. The prevailing NE-SW-oriented Alhama de Murcia Fault (AMF) crossing along these deposits (Figure 1a) represents the main active fault system of the study area (Martínez-Díaz et al., 2012). Underneath this sequence of materials, preorogenic deposits are present, which are composed of Paleozoic metamorphic complexes (IGME, 1981).

The Alto Guadalentín aquifer system covers an area of approximately $277 \mathrm{~km}^{2}$ (Figure 1a), and it is composed of Plio-Quaternary detrital and alluvial material, including clays, sands and conglomerates with clay and/or silt matrices; Miocene detritical with conglomerate and sand deposits; and local Triassic carbonate rocks. The Mesozoic marl and marl with intercalated sand and conglomerates represent the lower impermeable limit. The metamorphic substratum exhibits a horst and graben arrangement (Cerón and Pulido-Bosch, 1996); therefore, the depth of the impermeable limit varies within the region. In proximity of the East and West Basin borders, Tertiary deposits reach $400 \mathrm{~m}$ 
deep. In the N-E sector, the Alto Guadalentín aquifer is laterally linked to the multi-layer aquifer system of the Bajo Guadalentín aquifer (CHS, 2014). The transition zone between the two aquifers is characterized by thick clay layers that lose lateral continuity towards the Alto Guadalentín; therefore, locally semi-confined aquifers can be found in this zone. The spatial variability of the clayey material's thickness is evident from analysis of the available lithological columns (explained in subsection 4.1).

Since 1960, agricultural development has led to the exploitation of the aquifer system, which resulted in the aquifer being declared temporarily overexploited in 1987 (CHS, 2006). Although in the past, the piezometric level was close to the surface and artesian wells were exploited, groundwater drawdown became apparent in 1972 (Cerón and Pulido-Bosch, 1996). In 1988, the amount of extraction reached a maximum historical value of $77.6 \mathrm{hm}^{3} /$ year (IGME 1994). After 1988, a general reduction of pumping and/or abandonment of wells were recorded due to $\mathrm{CO}_{2}$ pollution of groundwater resources and to new sources of water transferred from the Tajo River to the Segura River (Cerón and Pulido-Bosch, 1996). In 2004, the last recorded extraction volume value was $43.3 \mathrm{hm}^{3} /$ year, with a reserve of $10 \mathrm{hm}^{3} /$ year. A deficit in the groundwater reserve was recorded from 1965 to 2009, corresponding to an annual rate of decline of $33 \mathrm{hm}^{3} /$ year (Alonso and Aróstegui, 2014).

In addition, the occurrence of drought periods, from 1990 to 1995 and from 2005 to 2007, increased the resource deficit (CHS, 2014). In particular, the first drought period triggered a nonlinear aquifer compaction episode due to the decrease of pore-pressure within the aquifer system (González and Fernández, 2011a).

The groundwater balance (Table 2) determined using available data from IGME (1994) and CHS (2005), illustrates the precarious situation of the aquifer due to the high deficit between the input and the output.

We have examined the historical evolution of the piezometric level from 1975 to 2012. Sources include data on the piezometric levels in 1975 and 1992 derived from Cerón $(1995,1999)$ (Figures 2a 
and 2b) and piezometric maps from 2008 (Figure 2c) and 2012 (Figure 2d) drawn by the Confederación Hidrográfica del Segura, the area's groundwater administration body (CHS, 2014). Cerón's piezometric maps for 1975 and 1992 were prepared by interpolating data from 28 and 57 piezometers, respectively. The Confederación Hidrográfica del Segura prepared piezometric maps by incorporating the means of the data from nine piezometers. The differences between these piezometric maps provide a qualitative estimate of piezometric drawdown between 1975 and 1992 (Figure 2e), 1992 and 2008 (Figure 2f), 2008 and 2012 (Figure 2g), and over the entire monitored period spanning 1975-2012 (Figure 2h). Overall, it can be observed that the highest and most extended water drawdown occurred in the first period ( $215 \mathrm{~m}$ maximum). In the second period, there was an extended recovery of the water level (65 m maximum), except for the western sector of the basin where the drawdown reaches a maximum value of $132 \mathrm{~m}$. The period from 2008 to 2012 highlights a recovery of the piezometric level (10 m maximum), except for the southern area of the basin where the drawdown reaches up to $31 \mathrm{~m}$. Based on these maps, most of the drawdown from 1975 to 2012 was due to water depletion that occurred in the first period (1975-1992). After 1992, water depletion mainly occurred in the western and southern areas of the basin. Widespread piezometric recuperation began in 1992 towards the eastern and northern areas followed by an overall stabilization in 2012, except for in the southern area. This spatial trend coincides with groundwater level variations of the piezometers located in the northern part of the basin (P3a, P3b, P4a, P4b and P5 in Figure 2i; see Figure 1a for their exact locations).

\section{Advanced DInSAR processing and results}

\subsection{SAR data and processing}

To study the temporal evolution of ground surface displacement in the Alto Guadalentín Basin, we collected and processed a large amount of C-band SAR data (ERS-1, ERS-2 and ENVISAT), L-band SAR data (ALOS PALSAR), and X-band SAR data (COSMO-SkyMed). 
Both ERS and ENVISAT-ASAR datasets, covering periods from 1992 to 2001 and from 2003 to 2007, were processed independently using DORIS interferometric software (Kampes et al., 2003) to handle all SAR data, including co-registration and interferogram generation. By adopting the small baseline approach (Berardino et al., 2002; González and Fernández, 2011b), we generated a line of sight (LOS) displacement time series using StaMPS software (Hooper, 2008). To determine the temporal evolution of the displacement, we merged the two results. Considering that ENVISAT-ASAR results were spatially denser (45\% more than the ERS, see Table 1), we used nearest-neighbour interpolation to transfer the ENVISAT-ASAR time series results to the ERS master grid. The two time series products were subsequently combined by minimizing the linear velocity change between the two separated time series (González and Fernández, 2011b). From this, we obtained a continuous time series of displacements for all pixels selected in the ERS dataset (7747 PS, see Table 1) from 1992 to 2007.

The ALOS PALSAR dataset from 2007 to 2010 and the COSMO-SkyMed dataset from 2011 to 2012 were processed independently using DIAPASON interferometric software for all SAR data handling. Additionally, SPN software (Arnaud et al., 2003, Duro et al. 2005) using the persistent scatterer approach was used to obtain three main products from a set of Single Look Complex (SLC) SAR images: (a) the average displacement velocity along the LOS of every pixel (PS), (b) a map of precise reflector heights (being the difference between the height given by the digital elevation model and the true height of each reflector), and (c) the LOS displacement time series of individual PS.

In both cases, a 25-m photogrammetrically derived digital elevation model was used to remove the topographic interferometric phase and to perform the final geocoding of results. Note that because the different sensors measure displacement using different incidence angles, the capacity to measure the vertical component of the displacement differs. For instance, ERS-1/2 and ENVISAT have a $23^{\circ}$ incidence angle, which permits the detection of $92 \%$ of vertical displacements, whereas ALOS and COSMO-SkyMed satellites only measure $83 \%$ and $75 \%$ of vertical displacements, respectively. 


\subsection{Advanced DInSAR results}

The persistent scatterer density retrieved from the combined ERS and ENVISAT dataset is approximately 4 to 99 times smaller than that obtained using the ALOS PALSAR and the COSMOSkyMed datasets, respectively (see Table 1). This variability is related to the spatial resolution of every sensor, the capacity to penetrate vegetation (which depends on the wavelength), temporal sampling and the type of processing.

In this case, we considered a threshold of $1 \mathrm{~cm} /$ year to indicate an area affected by significant subsidence. As a consequence, annual velocities in the range of $\pm 1 \mathrm{~cm} / \mathrm{yr}$ are considered stable (Figure 3) and are color-coded green, whereas yellow to red pixels indicate movement away from the satellite (subsidence). Less than 1\% of all PS show uplift; these are depicted in blue.

To homogenize the geometrical distortions introduced by the different acquisition angles of the various sensors, both the average velocity and the cumulative surface displacements in the LOS obtained for each dataset have been projected along the vertical direction. The total subsidence from 1992 to 2012 has been determined by taking into account the vertical cumulative surface displacements of the different datasets. The results show that cumulative displacement reached up to $250 \mathrm{~cm}$, with an average subsidence of $180 \mathrm{~cm}$ over an extension of $14.8 \mathrm{~km}^{2}$, located in the central sector of the Alto Guadalentín Basin (Figure 3d). The areal extent of the subsidence exhibits a SW-NE elliptical shape parallel to the valley direction, showing an apparent deceleration trend over time (Figs. 3a to $3 \mathrm{c}$ ). Note that the spatial extent of severe subsiding areas (faster than $-10 \mathrm{~cm} / \mathrm{yr}$ ) has been reduced from $14.4 \mathrm{~km}^{2}$ in $1992-2007$, to $11.7 \mathrm{~km}^{2}$ in $2007-2010$ and $7.4 \mathrm{~km}^{2}$ in $2011-2012$.

\subsection{Comparison with GPS time series}

DInSAR displacements were compared with vertical displacements measured by two continuous GPS stations (LOR1 and LORC; Figure 1a). The GPS stations are located in the north-western sector 
of the Alto Guadalentín Basin and belong to different networks (REGAM and MERISTEMUM) that developed by local institutions mainly for mapping, engineering and cadastral purposes. The LOR1 station is located in a relatively stable zone, while LORC is located in an area affected by higher subsidence rates. Raw GPS observations were processed using GAMIT/GLOBK software packages (Herring et al., 2010) by following the approach described by Palano (2015). To improve the overall configuration of the network and to tie regional measurements to an external global reference frame, data from $\sim 15$ continuously operating global tracking stations, largely from the EUREF (Beutler et al., 2008) permanent network, were introduced during processing. Daily time series were obtained by aligning our loosely constrained solutions with the ITRF2008 global reference frame (Altamimi et al., 2012).

The LOR 1 dataset covers the period $4^{\text {th }}$ September $2008-15^{\text {th }}$ June 2013 , while LORC spans the period $26^{\text {th }}$ August $2007-22^{\text {nd }}$ May 2013. For each of these, we superimposed the deformation time series considering the nearest PS from the GPS station, in a range less than $60 \mathrm{~m}$. DInSAR displacements have been converted into vertical movements assuming that ground deformation is purely vertical and considering that the ALOS PALSAR and the COSMO-SkyMed sensors identify $83 \%$ and $75 \%$ of the vertical deformations, respectively. The simple visual inspection of GPS and DInSAR time series (Figure 4) reveals good agreement between the different surveying techniques. To obtain a quantitative appraisal of DInSAR quality, first we computed the average $(\mu)$ and standard deviation $(\sigma)$ of the absolute differences between the two time series and then computed the average and standard deviation of the two series difference. The average and the standard deviation of the absolute difference are $4.7 \pm 4.0$ and $4.6 \pm 4.1 \mathrm{~mm}$ for the ALOS data at LOR1 and LORC stations, respectively. The difference between the two time series shows average values of $0.6 \pm 6.4 \mathrm{~mm}$ and 3.6 $\pm 5.2 \mathrm{~mm}$ for the LOR1 and LORC stations, respectively. Regarding the COSMO-SkyMed data, the absolute differences are $5.8 \pm 4.0 \mathrm{~mm}$ for LOR1 and $3.9 \pm 2.8 \mathrm{~mm}$ for LORC. The results of the 
difference between the two time series shows average values of $-4.8 \pm 5.2 \mathrm{~mm}$ for LOR1 and $3.4 \pm 3.2$ $\mathrm{mm}$ for LORC.

Recent validations of DInSAR performance with truth measurements (Strozzi et al., 2001; Hanssen 2003; Casu et al., 2006; Crosetto et al., 2008; Herrera et al. 2009; Tomás et al., 2010a) report error values within the range of $\pm 6.9 \mathrm{~mm}$. The measurements confirm the high reliability of the analysed DInSAR data. The vertical motion (subsidence in our case) estimated at the LORC station from 2008 to 2013, in averaged time intervals of 6 months, shows a decreasing rate beginning with an initial velocity of $\sim 10 \mathrm{~cm} / \mathrm{yr}$ and ending at $\sim 8 \mathrm{~cm} / \mathrm{yr}$ (see LORC time series in Figure 4). This feature is also visible in the COSMO-SkyMed displacement results (Figure 4).

We are aware that the use of only two GPS stations to sample a limited sector of the study area cannot adequately validate the DInSAR displacements over the entire investigated area. Unfortunately, the lack of additional measures of the vertical ground deformation field (e.g., levelling measurements and episodic GPS measurements) prevents us from validating the DInSAR displacements with independent measurements at the scale of the basin.

\section{Results analysis}

In this section, the InSAR data derived from three independent processes are spatially and temporally cross-compared with triggering factors (piezometric level variations) and conditioning factors of subsidence (the type and thickness of the different lithologies). Note that the analysis of the relationship between the groundwater overdraft, aquifer compaction and ground subsidence suffers from the low spatial resolution of geological and hydrogeological data.

\subsection{Comparison with lithology}


As previously mentioned, the Alto Guadalentín Basin is mainly filled by Holocene sediments. Towards the northwest area, older and less deformable sedimentary Pleistocene formations (alluvial fan, colluviums, piedmonts, etc.) are outcropping (Figure 1). By computing the average cumulated subsidence for each geological unit, we detected that the greatest cumulative subsidence value $(-0.5 \mathrm{~m})$ in the period 1992-2012, affects the Holocene sediments. For this time interval, Pleistocene sedimentary units account for a cumulative subsidence of $-0.2 \mathrm{~m}$, whereas Permian-Triassic and Miocene-Pliocene rock outcrops bordering the basin are the most stable, exhibiting no deformation. Therefore, as expected, the most recent units are affected by land subsidence, whereas older materials are less affected or are unaffected by this process. Taking into account the Plio-Quaternary isobaths map elaborated by Cerón and Pulido-Bosch (1996) (Figure 1b), we examined the relationship between the thickness of Plio-Quaternary filling and the subsidence rate estimated from the different available satellites (Figure 5, panels a, b and c). The results of this comparison suggest that maximum subsidence does not coincide with the thickest Plio-Quaternary filling. This could be explained by considering the different thickness of compressible materials such as silts, sands and clays within the Plio-Quaternary formations.

To solve this mismatch, we developed a soft soil thickness map (Figure 1c) based on the stratigraphic information available from 23 boreholes drilled for water pumping and hydrological research in the 1960s. The soft soil thickness for each borehole was calculated as the total thickness of the silt and clay-type layers located over the upper layer of gravels above the substratum. An ordinary Kriging interpolation method was used to predict the soft soil thickness where borehole data were lacking. It can be observed that soft soils thicker than $100 \mathrm{~m}$ are located in the central part of the basin towards the northeast (Figure 1c), whereas towards the southwest and bordering areas of the basin, thinner soft soils are found. In this case, the relationship between soft soil thickness and subsidence rates estimated from the different satellites is straightforward; i.e., maximum subsidence rates are 
found on the thickest soft soils (Figures 5, panels d, e and f), and contrarily, the average subsidence values estimated for the thinnest soft soils are within the stable range.

\subsection{Comparison with piezometry}

Ground surface displacements estimated using advanced DInSAR were compared with groundwater variations observed spatially for the different time intervals (Figures 6 and 7), as well as with local data recorded by piezometers (Figure 8).

Ground water drawdown estimated from 1975 to 2012 was compared with cumulative displacements from 1992 to 2012, which were obtained by adding the displacements estimated by ERS and ENVISAT, ALOS satellites and COSMO-SkyMed. The results from this comparison show no clear correlation between these measures (Figure 6). Indeed, in the period 1992-2008, the highest water drawdown $(>125 \mathrm{~m})$ corresponds to an average subsidence of $0.02 \mathrm{~cm}$, whereas the maximum recovery of the piezometric level (up to $75 \mathrm{~m}$ ) coincides with an average subsidence of $12.4 \mathrm{~cm}$ (Figure 6a). Similarly, no clear correlation is apparent when comparing groundwater drawdown with cumulative displacements measured from 2008 to 2012 (Figure 6b). Thus, the highest subsidence (52.2 $\mathrm{cm}$ ) occurs where water recovery is recorded (up to $25 \mathrm{~m}$ ). Finally, the comparison between groundwater drawdown from 1975 to 1992 and the cumulative displacements from 1992 to 2012 reveals a clear correlation. Hence, a greater groundwater drawdown corresponds to a greater cumulative subsidence (Fig. 6c). Therefore, it is reasonable to consider that the displacements observed from 1992 to 2012 could be due to the piezometric drawdown beginning in the 1970s, which corresponds to a longer delayed compaction process than that suggested by González and Fernández (2011a) for the 1990-1995 drought period.

The comparison of variables, subsidence and groundwater drawdown along two transects, $\mathrm{A}^{-\mathrm{A}^{\prime}}$ and B$\mathrm{B}^{\prime}$ (Figures 7a to 7f), shows their relationship to the thickness of the compressible deposits and the depth of the substratum (Cerón and Pulido-Bosch, 1996) (Figures 7c, 7f). As shown in Figures 7a and 
$7 \mathrm{~b}$, there seems to be a deceleration during the period 2011-2012 with respect to previous periods (1992-2007 and 2007-2010). No clear relationship is observed between measured cumulative displacement in the periods 1992-2008 and 2008-2012 and groundwater evolution (Figures 7b and 7e) in either transect. Note that the stabilization of the piezometric level in the period 2008-2012 does not coincide with the measured subsidence pattern. Contrarily, good agreement is observed if we consider groundwater depletion measured since 1975 and cumulative displacements.

A detailed time series analysis of subsidence and ground water evolution is presented for the seven available piezometers (Figure 8). The water table level ranges from 200 to $275 \mathrm{~m}$ a.s.1 in 1975 and between 70 and $160 \mathrm{~m}$ a.s.1 in 2013 (Figure 2i). No correlation is observed at piezometer P1, located in the southern zone, where the highest groundwater drawdown (162 m) from 1992 to 2007 corresponds to $13 \mathrm{~cm}$ of cumulated subsidence in the period 1992-2012 (Figure 8a and Table 3). This is likely due to the absence of soft soils in the southern border of the basin, where conglomerates with a sand-clay matrix from the alluvial fans are dominant (Figure 1c).

Certain correlation is observed in the western part of the basin (piezometers P2, P4a and P4b) where the soft soil thickness is moderate (from 18 to $21 \mathrm{~m}$ ). In this sector, groundwater drawdowns between 31 and $107 \mathrm{~m}$ in the period 1992-2007 correspond to cumulative subsidence in the range of 38 to 48 $\mathrm{cm}$ during the period 1992-2012 (Table 3). Piezometer P2 displays a steady lowering of the piezometric level from 1989 to 2013 (Figure 8b) that correlates well with a more or less steady subsidence rate. Contrarily, piezometers $\mathrm{P} 4 \mathrm{a}-\mathrm{b}$, which are jointly analysed due to their proximity and characteristics (Figure 1a), exhibit a high ground water level variability that is not in agreement with the estimated subsidence linear rate (Figure 8d).

In the eastern part of the basin, piezometers P3a-b display a water level evolution that is in agreement with subsidence accelerations and decelerations. The piezometric lowering observed in the period 1992-2007 (Figure 8c) coincides with the transient compaction of the aquifer previously reported by 
González and Fernández (2011a), which was followed by piezometric recovery until 2012 when the subsidence progressively decelerated (Table 3).

In the central part of the basin where the thickest soft soils are found (approximately $190 \mathrm{~m}$ ), the time series of piezometer P5 reveals a groundwater level recovery from 2007 to 2013 that does not correspond with measured subsidence steady rates (Figure 8e). This indicates an inelastic, unrecoverable and permanent deformation of this aquifer, as previously reported by Rigo et al. (2013), which was triggered by the groundwater exploitation beginning in the early 1970s.

Overall, a clear correlation between groundwater level drawdown and subsidence accelerations/decelerations is not observed (Table 3, Figure 8). This uncorrelation is related to the presence of very thick (>100 m) unconsolidated sediments (clay and silts) that are responsible for an apparent time delay between water level depletion and ground surface displacement. Indeed, most of these fine-grained silt and clay layers with low vertical hydraulic conductivity (approximately 50 $\mathrm{mm} / \mathrm{h}$ ) and slow deformability have been drained since the $1970 \mathrm{~s}$ due to the negative gradient of the pore pressure as a result of aquifer overexploitation (Figure $2 \mathrm{~h}$ ).

\subsection{Subsidence analysis}

The calculation of subsidence-induced ground settlement $(\delta)$ triggered by groundwater abstraction is usually performed with consideration of three parameters: (a) the thickness of deformable soils $(\mathrm{H})$, which is spatially correlated with the calculated settlements discussed in subsection 4.1; (b) the variation in the stress state due to groundwater drawdown $(\Delta \mathrm{h})$ since the 1970 s (subsection 4.2 ), which is responsible for the effective stress increase, causing the consolidation of deformable soils; and (c) the deformability of the soil, which mainly depends on the nature of the different layers that constitute the aquifer system and its geological history. 
Under a certain effective stress increase, a larger deformation is expected in soil than in rock, and a normally consolidated soil is potentially more deformable than an overconsolidated soil (Tomás et al. 2010b). This can be clearly observed in Figure 3, in which lower values of subsidence are found in the border area and the reliefs. In these areas, older rocky lithologies are generally present, in comparison with the younger Holocene sediments that fill the valley and exhibit the greatest subsidence values.

The settlement calculation derived from these three parameters corresponds to the deformation $(\delta)$ of the soft soil thickness $(H)$ after the whole excess pore pressure $(\Delta \mathrm{u})$ induced by a piezometric level change has been dissipated. Therefore, during transient situations of the soil consolidation process (i.e., those situations in which $\Delta \mathrm{u} \neq 0$ ), settlement will be lower than $\delta$. Consequently, the magnitude of the settlement measured at certain times during the consolidation process will also depend on time. Hence, the total deformation will only be reached when all of the excess pore pressure is drained from the soil. This process can be very quick for permeable soils (at times, almost instantaneously) or quite slow (years to decades) for fine soils with very low permeability.

Pumping tests performed in the Alto Guadalentín basin differentiate four typologies of soils and hydrogeological behaviours (CHS, 1990): highly fine soil (interbed) with a permeability value lower than $50 \mathrm{~mm} / \mathrm{h}$, fine soil with a permeability value of $50-90 \mathrm{~mm} / \mathrm{h}$, medium soil with a permeability value of $90-120 \mathrm{~mm} / \mathrm{h}$, and coarse soil with a permeability value of up to $120 \mathrm{~mm} / \mathrm{h}$.

Therefore, due to the low vertical hydraulic permeability of fine-grained silts and clays (approximately $50 \mathrm{~mm} / \mathrm{h}$ ), the excess pore pressure in the interbed is dissipated with a delay with respect to the dissipation of the pore pressure in the aquifer system.

In this case study, a joint comparison of all of the available data suggests that the aquifer system is suffering a delayed compaction process, where the maximum settlement has still not been reached. This interpretation is in agreement with the observed trend of the time-subsidence curves derived from 
InSAR and GPS data (Figures 4 and 8), which indicates that the aquifer system deformation is suffering a deceleration that coincides with the theoretical consolidation curves obtained from laboratory tests for unconsolidated sediments. In the future, the execution of a deep geotechnical borehole will allow for laboratory tests to be conducted to clarify the role of soil deformability and to model the behaviour of this aquifer system.

\section{Discussion}

In this paper, subsidence triggered by overexploitation of the Alto Guadalentín aquifer system is investigated through the collection and analysis of geological and hydrological information combined with displacement maps and time-series retrieved from multi-sensor and multi-temporal SAR images. Advanced DInSAR techniques have been used to process ALOS PALSAR (2007-2010) and COSMOSkyMed (2011-2012) SAR images. Both low- and high-resolution images provide similar subsidence patterns for the entire study area. These results have been combined with previously published displacement measurements obtained from ERS and ENVISAT satellite SAR images for the period 1992-2007, which allow for the mapping and monitoring of subsidence phenomenon due to Alto Guadalentín aquifer overexploitation between 1992 and 2012.

Retrieved subsidence maps reveal a $13 \mathrm{~km}$ x $4 \mathrm{~km}$ SW-NE lengthened subsidence area parallel to the Guadalentín valley direction, which exhibits subsidence rates higher than $5 \mathrm{~cm} / \mathrm{yr}$ and a $250-\mathrm{cm}$ maximum cumulative displacement in the 20 -year monitoring period.

Although the area affected by subsidence is similar among the different monitoring periods and sensor resolutions, there seems to be a slight deceleration during the period 2011-2012 with respect to the previous periods (1992-2007 and 2007-2010). These results obtained from multi-sensor and multitemporal SAR images have been compared with GPS measurements, showing errors of $4.6 \pm 4 \mathrm{~mm}$ for the ALOS data and $4.8 \pm 3.5 \mathrm{~mm}$ for the COSMO-SkyMed data. 
The Alto Guadalentín aquifer system is formed by Plio-Quaternary and Miocene detrital materials that can reach 400 m deep with a lower impermeable limit formed by Mesozoic marls and conglomerates. Although the presence of Plio-Quaternary sediments coincides well with measured displacements, there is not a direct relationship between their thickness and the magnitude of the displacement rate. This can be explained by the spatial variability of the grain size and the thickness of Plio-Quaternary sediment.

Stratigraphic information from 23 boreholes drilled for water pumping in the 1960s was analysed to determine the spatial variability of Plio-Quaternary sediments. An area of $22 \mathrm{~km}^{2}$ where soft soils (i.e., clays and silts) are thicker than $100 \mathrm{~m}$ has been identified in the central part of the basin towards the northeast (Figure 1c), where the transition zone between Alto and Bajo Guadalentín aquifers is found. Contrarily, on the bordering areas of the basin and particularly towards the southwest, thinner compressible soils alternate with thick layers of gravels and conglomerates from alluvial fans, colluviums and piedmonts (Silva et al. 2008). In this case, a clear correlation is observed between measured displacement rates and the soft soil thickness map.

Recompilation and analysis of the available piezometric information has provided a qualitative estimate of the spatial and temporal evolution of groundwater drawdown between 1975 and 2012 (Figure 2). This analysis reveals that the most intense groundwater drawdown occurred from 1975 to 1992 (215 m maximum), followed by a partial recovery and groundwater level stabilization until 2012. Currently, most of the pumping wells are located in this southern and southwestern sector of the aquifer, which is responsible for the deficit of the groundwater reserve.

Comparison of the spatial and temporal evolution of the aquifer groundwater level to estimated displacements does not reveal a clear correlation between groundwater level variations and subsidence rate changes. As previously reported by Rigo et al. (2013), the aquifer system is affected by inelastic, unrecoverable and permanent deformation, indicating a delayed compaction process longer in time than that suggested by González and Fernández (2011a). 
This hypothesis is supported by the presence of a very thick (>100 m) soft soil layer with a very low permeability (approximately $50 \mathrm{~mm} / \mathrm{h}$ ), which is responsible for the very slow consolidation process. Indeed, most of the fine-grained silt and clay layers with low vertical hydraulic conductivity have been drained since the 1960s due to aquifer overexploitation and the negative gradient of the pore pressure has persisted since that time (Figure 2h). This negative gradient is responsible for a delayed consolidation process, wherein the maximum settlement has still not been reached.

This hypothesis is in agreement with the observed trend of time-subsidence curves derived from InSAR and GPS data, which indicate that the aquifer system deformation is suffering a deceleration coinciding with the theoretical consolidation curves obtained from laboratory tests for unconsolidated sediments. In the future, the execution of a deep geotechnical borehole allows for laboratory tests to be conducted to better understand the role of soil deformability and to model the behaviour of this aquifer system.

\section{Conclusions}

In this paper, the combined analysis of geological and hydrological information with displacement maps and time-series retrieved from multi-sensor and multi-temporal SAR images generates several novel conclusions with respect to previous works:

1) A 20-year spatio-temporal evolution of subsidence was determined using DInSAR techniques where the accumulated subsidence due to overexploitation of the Alto Guadalentín aquifer system reaches maximum values of $2.5 \mathrm{~m}$. Additionally, the satellite measurements provide locally comparable results with measurements acquired by two permanent GPS stations located in the study area.

2) The spatial variability of the grain size and thickness of Plio-Quaternary sediments was determined, informing the development of a new soft soil thickness map, which correlates well with the magnitude of measured displacements. 
3) The spatio-temporal evolution of groundwater between 1975 and 2012 revealed that the most intense drawdown occurred from 1975 to 1992 (215 m maximum), followed by partial recovery and groundwater level stabilization until 2012; this points to an unclear correlation with the displacement time series.

These findings suggest that the aquifer system is experiencing a very slow consolidation process where a very thick soft soil layer with low permeability has been drained since the 1960s due to aquifer overexploitation. As a result, a negative gradient is maintained in this layer, which creates a delayed consolidation process wherein the maximum settlement has yet to be reached.

\section{Acknowledgments}

This work was developed during Roberta Bonì stay within the Geohazards InSAR laboratory and Modeling group of the Instituto Geológico y Minero de España in the framework of DORIS project (Ground Deformation Risk Scenarios: an Advanced Assessment Service) funded by the EC-GMESFP7 initiative (Grant Agreement 423 n $^{\circ}$ 242212). ALOS PALSAR images were provided by the project JAXA-1209. Part of this work is supported by the Spanish Government under project TEC2011-28201C02 and by the project 15224/PI/10 from the Regional Agency of Science and Technology in Murcia. Additional funding was obtained from Spanish Research Program through the projects AYA201017448, ESP2013-47780-C2-1-R and ESP2013-47780-C2-2-R and by the Ministry of Education, Culture and Sport trough the project PRX14/00100.

\section{Conflicts of Interest}

The authors declare no conflict of interest.

\section{References and Notes}


Alonso, M., S., and Aróstegui, J., L., G. (2014) Sobreexplotación de acuíferos en la cuenca del Segura, ISBN: 978-84-92988-22-8.

Altamimi, Z., Métivier, L., Collilieux, X. (2012). ITRF2008 plate motion model. J. geophys. Res. 117, B07402, doi:10.1029/2011JB008930.

Arnaud A., Adam, N., Hanssen, R., Inglada, J., Duro, J., Closa, J. Eineder M. (2003). ASAR ERS interferometric phase continuity. International Geoscience and Remote Sensing Symposium, 2125 July 2003, Toulouse (France).

Berardino, P., Fornaro, G., Lanari, R., Sansosti, E. (2002). A new algorithm for surface deformation monitoring based on small baseline differential SAR interferograms. Geoscience and Remote Sensing, IEEE Transactions on, 40 (11), 2375-2383.

Beutler, G., Moore, A.W., Mueller, I.I. (2008). The International Global Navigation Satellite Systems (GNSS) Service: developments and achievements. Journal of Geodesy, 83 (3-4), 297-307, doi:10.1007/s00190-008-0268-z.

Bourgois, J., Mauffret, A., Ammar, A., Demnati, A. (1992). Multichannel seismic data imaging of inversion tectonics of the Alboran Ridge (Western Mediterranean Sea). Geo-Marine Letters, 12 $(2-3), 117-122$.

Casu, F., Manzo, M., Lanari, R. (2006). A quantitative assessment of the SBAS algorithm performance for surface deformation retrieval from DInSAR data. Remote Sensing of Environment, 10 2(3), 195-210.

Cerón, J.C. (1995), Estudio hidrogeoquimico del acuifero del Alto Guadalentín (Murcia) [Ph.D. 229 thesis]: Granada, University of Granada, pp. 265. 
Cerón, J.C., and Pulido-Bosch, A. (1996). Groundwater problems resulting from CO2 pollution and overexploitation in Alto Guadalentín aquifer (Murcia, Spain). Environmental Geology, 28 (4) 223-228, doi:10.1007/s002540050096.

Cerón, J. C., Pulido-Bosch, A., Bakalowicz, M. (1999). Application of Principal Components Analysis to the study of CO2-rich thermomineral waters in the aquifer system of Alto Guadalentín (Spain). Hydrological sciences journal, 44 (6), 929-942.

Changming, L., Jingjie, Y., Kendy, E. (2001). Groundwater exploitation and its impact on the environment in the North China Plain. Water International, 26 (2), 265-272.

CHS (1990), Estudio y redacción del Plan de ordenación del acuífero Alto Guadalentín, Tech. rep.

CHS (2005), Estudio de cuantificación del volumen anual de sobreexplotación de los acuíferos de la unidad hidrogeológica 07.28 Alto Guadalentín y 07.33 Águilas, Tech. rep.

ftp://ftp.chsegura.es/oph/phcsegura/borrador/anejo12docs/FichaSub_070_057_AltoGuadalentin.pdf

CHS (2006), Plan especial ante situaciones de alerta y eventual sequia en la cuenca del Segura: 238 Confederacion hidrografica del Segura, Tech. rep., 298 p., 239.

CHS (2014), Plan Hidrológico de la Cuenca del Segura 2015/2021. Análisis piezométrico histórico y de los ultimos 25 años (1990-2014) de las masas de Agua subterráneas de la demarcación Hidrográfica del Segura. 070.057 Alto Guadalentín. Tech. rep.

http://www.chsegura.es/chs/cuenca/sequias/pes/eeapes.html\#doc_completa

Crosetto, M., Biescas, E., Duro, J., Closa, J., Arnaud A. (2008). Generation of Advanced ERS and Envisat Interferometric SAR Products Using the Stable Point Network Technique. Photogrammetric Engineering \& Remote Sensing, 74 (4), 443-450. 
Declercq, P.-Y., Devleeschouwer, X., Pouriel, F. (2005). Subsidence Revealed by PSInSAR Technique in the Ottignies-Wavre Area (Belgium) Related to Water Pumping in Urban Area. Fringe 2005 Workshop, Proceedings of the Conference held 28 November -- 2 December, 2005 in Frascati, Italy. Edited by H. Lacoste and L. Ouwehand. ESA SP-610. European Space Agency, 2006. Published on CDROM., p.66.1.

Duro J., Inglada, J., Closa, J., Adam, N. Arnaud A. (2003). High resolution differential interferometry using time series of ERS and ENVISAT SAR data. FRINGE 2003, 1-5 December 2003, Frascati (Italy).

Ferretti A., Prati C., Rocca F. (2001). Permanent scatterers in SAR interferometry. IEEE Trans Geosci Remote Sens 39(1), 8-20, doi:10.1109/36.898661.

Galloway, D. L., Hudnut, K. W., Ingebritsen, S. E., Phillips, S. P., Peltzer, G., Rogez, F., Rosen, P. A. (1998). Detection of aquifer system compaction and land subsidence using interferometric synthetic aperture radar, Antelope Valley, Mojave Desert, California. Water Resources Research, 34(10), 2573-2585.

González, P. J., Fernández, J. (2011a). Drought-driven transient aquifer compaction imaged using multitemporal satellite radar interferometry. Geology, 39 (6), 551-554, doi:10.1130/G31900.1.

González P.J., Fernández J. (2011b). Error estimation in multitemporal InSAR deformation time series, with application to Lanzarote, Canary Islands, Journal of Geophysical Research, 116, B10404, doi:10.1029/2011JB008412.

González, P. J., Tiampo, K. F., Palano, M., Cannavó, F., Fernández, J. (2012). The 2011 Lorca earthquake slip distribution controlled by groundwater crustal unloading. Nature Geoscience, 5 (11), 821-825, doi:10.1038/ngeo1610. 
Gràcia, E., Pallàs, R., Soto, J. I., Comas, M., Moreno, X., Masana, E., Santanach, P., Diez, S., García, M., Dañobeitia, J.J. (2006). Active faulting offshore SE Spain (Alboran Sea): Implications for earthquake hazard assessment in the Southern Iberian Margin. Earth and Planetary Science Letters, 241(3), 734-749, doi:10.1016/j.epsl.2005.11.009.

Hanssen, R. F. (2003, May). Subsidence monitoring using contiguous and PS InSAR quality assessment based on Precision and Reliability. In The 11th FIG Symposium on DeformationMeasurements, Santorini, Greece.

Herrera, G., Fernández, J.A., Tomás, R., Cooksley, G., Mulas, J. (2009). Advanced interpretation of subsidence in Murcia (SE Spain) using A-DInSAR data - modelling and validation. Natural Hazards and Earth System Science 9, 647-661.

Hoffmann, J., Zebker, H.A., Galloway, D.L., Amelung, F. (2001). Seasonal subsidence and rebound in Las Vegas Valley, Nevada, observed by synthetic aperture radar interferometry. Water Resources Research 37, 1551-1566.

Holzer, T.L., Galloway, D.L. 2005. Impacts of land subsidence caused by withdrawal of underground fluids in the United States. Reviews in Engineering Geology, XVI, 87-99.

Hooper, A. (2008). A multi-temporal InSAR method incorporating both persistent scatterer and small baseline approaches. Geophys. Res. Lett. 35(16), L16302, doi:10.1029/2008GL034654.

IGME (1981). Mapa Geologico de España, 1:50.000, Sheet Lorca (953). Servicio de Publicaciones Ministerio de Industria, Madrid.

IGME (1994). Estudio para la regulación y apoyo a la gestión de los recursos hídricos subterráneos del Alto Guadalentín (Murcia). Modelo matemático de flujo subterráneo. IGME internal report ref. 33237. 
Kampes, B. M., Hanssen, R. F., Perski, Z. (2003, December). Radar interferometry with public domain tools. In Proceedings of FRINGE (pp. 1-5).

Lundgren, P., Usai, S., Sansosti, E., Lanari, R., Tesauro, M., Fornaro, G., Berardino, P. (2001). Modeling surface deformation observed with synthetic aperture radar interferometry at Campi Flegrei caldera. J. Geophys. Res., 106 (B9), 19355-19366, doi:10.1029/2001jb000194.

Martín, V. J. M., Espinosa, G. J. S., Pérez, R. A. (1973). Mapa geológico de España: E. 1:50,000. Madrid: Servicio de Publicaciones, Ministerio de Industria y Energía. Instituto geológico y minero de España (IGME).

Martınez-Diaz, J. J. (2002). Stress field variation related to fault interaction in a reverse oblique-slip fault: the Alhama de Murcia fault, Betic Cordillera, Spain. Tectonophysics 356 (4), 291-305.

Martínez-Díaz, J. J., Bejar-Pizarro, M., Álvarez-Gómez, J. A., Mancilla, F. D. L., Stich, D., Herrera, G., Morales, J. (2012). Tectonic and seismic implications of an intersegment rupture: The damaging May 11th 2011 Mw 5.2 Lorca, Spain, earthquake. Tectonophysics 546, 28-37.

Masana, E., Martínez-Díaz, J. J., Hernández-Enrile, J. L., Santanach, P. (2004). The Alhama de Murcia fault (SE Spain), a seismogenic fault in a diffuse plate boundary: Seismotectonic implications for the Ibero-Magrebian region. J. Geophys. Res. 109, B01301, doi:10.1029/2002JB002359.

Mora, O., Mallorqui, J.J., Broquetas, A. (2003). Linear and nonlinear terrain deformation maps from a reduced set of interferometric SAR images. IEEE Trans. Geosci. Remote Sens. 41(10), 22432253.

Palano, M., González, P., Fernández, J. (2013). Strain and stress fields along the Gibraltar Orogenic Arc: constraints on active geodynamics. Gondwana Res. 23, 1071-1088, doi:10.1016/j.gr.2012.05.021. 
Palano, M. (2015). On the present-day crustal stress, strain-rate fields and mantle anisotropy pattern of Italy. Geophys. J. Int., 200 (2), 969-985, doi:10.1093/gji/ggu451.

Phien-Wej, N., Giao, P. H., Nutalaya, P. (2006). Land subsidence in Bangkok, Thailand. Eng. Geol.82 (4), 187-201.

Prati, C., Ferretti, A., Perissin, D. (2010). Recent advances on surface ground deformation measurement by means of repeated spaceborne SAR observations. J. Geodyn. 49 (3-4), 161-170, doi: 10.1016/j.jog.2009.10.011.

Rigo, A., Béjar-Pizarro, M., Martínez-Díaz, J. (2013). Monitoring of Guadalentín valley (southern Spain) through a fast SAR Interferometry method. J. Appl. Geophys. 91, 39-48.

Sansosti, E., Casu, F., Manzo, M., Lanari R. (2010). Space-borne radar interferometry techniques for the generation of deformation time series: an advanced tool for Earth's surface displacement analysis. Geophys. Res. Lett. 37(20), L20305, doi:10.1029/2010g1044379.

Schmidt, D.A., Bürgmann R. (2003). Time-dependent land uplift and subsidence in the Santa Clara valley, California, from a large interferometric synthetic aperture radar data set. J. Geophys. Res. 108, B92416, doi:10.1029/2002jb002267.

Silva, P. G., Bardají, T., Calmel-Avila, M., Goy J. L., Zazo, C. (2008). Transition from alluvial to fluvial systems in the Guadalentín Depression (SE Spain) during the Holocene: Lorca Fan versus Guadalentín River. Geomorphology, 100, 140-153.

Stramondo, S., Saroli, M., Tolomei, C., Moro, M., Doumaz, F., Pesci, A., Loddo, F., Baldi, P., Boschi, E. (2007). Surface movements in Bologna (Po Plain-Italy) detected by multitemporal DInSAR. Remote Sensing of Environment, 110 (3), 304-316. 
Strozzi, T., Wegmuller, U., Tosi, L., Bitelli, G., Spreckels, V. (2001). Land subsidence monitoring with differential SAR interferometry. Photogrammetric engineering and remote sensing, 67 (11), 1261-1270.

Tomás, R., Herrera, G., Delgado, J., Lopez-Sanchez, J.M., Mallorquí, J.J., Mulas, J. (2010a). A ground subsidence study based on DInSAR data: calibration of soil parameters and subsidence prediction in Murcia City (Spain). Eng. Geol. 111, 19-30.

Tomás, R., Herrera, G., Lopez-Sanchez, J.M., Vicente, F., Cuenca, A. \& Mallorquí, J.J. (2010b). Study of the land subsidence in Orihuela City (SE Spain) using PSI data: Distribution, evolution and correlation with conditioning and triggering factors. Engineering Geology, 115, 105-121.

Tomás, R., Romero, R., Mulas, J., Marturià, J.J., Mallorquí, J.J., Lopez-Sanchez, J.M., Herrera, G., Gutiérrez, F., González, P.J., Fernández, J., Duque, S., Concha-Dimas, A., Cocksley, G., Castañeda, C., Carrasco, D., Blanco, P. (2014). Radar interferometry techniques for the study of ground subsidence phenomena: a review of practical issues through cases in Spain. Environmental Earth Sciences 71, 163-181.

Werner, C., Wegmuller, U., Strozzi, T., Wiesmann, A. (2003). Interferometric point target analysis for deformation mapping. In: Geoscience and remote sensing symposium, IGARSS ‘03. Proceedings. 2003 IEEE International, 21-25 July 2003 pp 4362-4364 vol.4367. doi:10.1109/igarss.2003.1295516. 
Click here to download Table: Tables.docx

Table 1. Details on the SAR data sets, their processing and results.

\begin{tabular}{|c|c|c|c|c|}
\hline Satellite & ERS-1/2 & ENVISAT & ALOS PALSAR & COSMO_SkyMed \\
\hline$\lambda(\mathrm{cm})$ & 5.6 (C-band) & 5.6 (C-band) & 22.9 (L-band) & $3.1(X-b a n d)$ \\
\hline Orbit & Desc. & Desc. & Asc. & Asc. \\
\hline Look angle $(\stackrel{\circ}{)})$ & 23 & 23 & 34 & 42 \\
\hline Time span & $\begin{array}{c}\text { 22/06/1992 } \\
- \\
\text { 21/12/2000 }\end{array}$ & $\begin{array}{c}15 / 03 / 2003 \\
- \\
15 / 03 / 2007\end{array}$ & $\begin{array}{c}19 / 01 / 2007 \\
- \\
14 / 06 / 2010\end{array}$ & $\begin{array}{c}17 / 05 / 2011 \\
- \\
14 / 10 / 2012\end{array}$ \\
\hline Number of scenes & 32 & 19 & 14 & 83 \\
\hline Processing technique & StaMPS & StaMPS & SPN & SPN \\
\hline Georeference accuracy & 25 & 25 & 10 & 5 \\
\hline №. PS & 7747 & 11120 & 28196 & 761339 \\
\hline PS density (PS/km²) & 33 & 48 & 120 & 3254 \\
\hline Vel. (cm/yr) & \multicolumn{2}{|c|}{$-2.0 \pm 3.2$} & $-2.5 \pm 2.9$ & $-1.3 \pm, 1.8$ \\
\hline Vel. Range (Max; Min) & \multicolumn{2}{|c|}{$0.5 ;-11.9$} & $2.1 ;-12.8$ & $2.3 ;-11.4$ \\
\hline
\end{tabular}


Table 2. Groundwater balance components for Alto Guadalentín aquifer, based on data from IGME 1994, and CHS 2005 (Values in $\mathrm{hm}^{3} / \mathrm{yr}$ ). $\mathrm{I}_{\mathrm{ES}}$ : runoff infiltration; $\mathrm{I}_{\mathrm{D}}$ : direct infiltration from rain; $\mathrm{R}_{\mathrm{R}}$ : irrigation return; $S_{\mathrm{BN}}$ : net output by pumping.

\begin{tabular}{|c|c|c|c|c|}
\hline \multicolumn{2}{|c|}{ Budget item } & $\begin{array}{c}\text { Dry year } \\
(2003-2004)\end{array}$ & $\begin{array}{l}\text { Average year } \\
(1976-1988)\end{array}$ & $\begin{array}{c}\text { Wet year } \\
\text { (1989) }\end{array}$ \\
\hline & & CHS 2005 & IGME 1994 & IGME 1994 \\
\hline \multirow{4}{*}{ Input } & $\mathrm{I}_{\mathrm{ES}}$ & 3.1 & 5.3 & 12.4 \\
\hline & $I_{D}$ & 1.2 & 8.0 & 32.8 \\
\hline & $\mathrm{R}_{\mathrm{R}}$ & 7.2 & 8.8 & 6.9 \\
\hline & Total & 11.5 & 22.1 & 52.1 \\
\hline Output & $\mathrm{S}_{\mathrm{BN}}$ & 43.3 & 50 & 60 \\
\hline \multicolumn{2}{|c|}{ Storage variation } & -31.8 & -27.9 & -7.9 \\
\hline
\end{tabular}

Table 3. Piezometers dataset. The water level variations, the subsidence and the rate of the displacements considering three time intervals (1992-2007, 2007-2010, 2011-2012) and for the whole monitored period (1992-2012) are specified for each piezometer. The rate indicates the vertical velocity measured at the PS closest respect to the piezometer. CSK stands for the COSMOSkyMed data.

\begin{tabular}{|c|c|c|c|c|c|c|c|c|c|}
\hline Piez. & $\begin{array}{l}\text { Monitored } \\
\text { period }\end{array}$ & $\begin{array}{l}\text { Ground } \\
\text { surface } \\
\text { [m a.s.l.] }\end{array}$ & $\begin{array}{l}\text { Quat. } \\
\text { depht } \\
\text { [m] }\end{array}$ & $\begin{array}{c}\text { Softsoil } \\
\text { thikness } \\
{[\mathrm{m}]}\end{array}$ & Parameters & $\begin{array}{c}1992- \\
2007 \\
\text { ERS-ENV }\end{array}$ & $\begin{array}{c}2007-2010 \\
\text { ALOS }\end{array}$ & $\begin{array}{l}2011- \\
2012 \\
\text { CSK }\end{array}$ & $\begin{array}{l}1992 \\
2012\end{array}$ \\
\hline \multirow{4}{*}{$\mathrm{P} 1$} & \multirow{3}{*}{$1984-2007$} & \multirow{3}{*}{317.75} & \multirow{3}{*}{$200-300$} & \multirow{3}{*}{0.97} & $\begin{array}{l}\text { Water Level } \\
\text { variation [m] }\end{array}$ & -162 & - & - & - \\
\hline & & & & & Subsidence [m] & 0 & 0 & 0.13 & 0.13 \\
\hline & & & & & Rate $[\mathrm{cm} / \mathrm{yr}]$ & 0 & -0.5 & -0.3 & - \\
\hline & \multirow{3}{*}{$1989-2013$} & \multirow{3}{*}{359.08} & \multirow{3}{*}{$200-300$} & \multirow{3}{*}{20.53} & $\begin{array}{l}\text { Water Level } \\
\text { variation [m] }\end{array}$ & -31 & -2 & -2 & -35 \\
\hline \multirow[t]{2}{*}{ P2 } & & & & & Subsidence [m] & -0.40 & -0.06 & -0.02 & -0.48 \\
\hline & & & & & Rate $[\mathrm{cm} / \mathrm{yr}]$ & -2.4 & -1.6 & -2.6 & - \\
\hline P3a & 1986-2009 & 289.69 & $100-200$ & 60.52 & $\begin{array}{l}\text { Water Level } \\
\text { variation [m] }\end{array}$ & -25 & 4 & 11 & -10 \\
\hline
\end{tabular}




\begin{tabular}{|c|c|c|c|c|c|c|c|c|c|}
\hline \multirow{3}{*}{ P3b } & \multirow{3}{*}{$2009-2013$} & \multirow{3}{*}{287.69} & & & Subsidence [m] & -0.05 & -0.01 & 0 & -0.06 \\
\hline & & & & & & & & & \\
\hline & & & & & Rate $[\mathrm{cm} / \mathrm{yr}]$ & -0.3 & -0.1 & 0.2 & - \\
\hline \multirow[t]{2}{*}{$\mathrm{P} 4 \mathrm{a}$} & $1972-2008$ & 271.62 & \multirow{4}{*}{$200-300$} & & $\begin{array}{l}\text { Water Level } \\
\text { variation [m] }\end{array}$ & -107 & 11 & -6 & -102 \\
\hline & & & & 17.92 & Subsidence [m] & -0.30 & -0.06 & -0.02 & -0.38 \\
\hline \multirow[t]{3}{*}{ P4b } & 2009-2013 & 318 & & & & & & & \\
\hline & & & & & Rate $[\mathrm{cm} / \mathrm{yr}]$ & -3 & -2 & -1 & - \\
\hline & & & & & $\begin{array}{l}\text { Water Level } \\
\text { variation [m] }\end{array}$ & $-15^{*}$ & 5 & -6 & $16^{*}$ \\
\hline \multirow[t]{2}{*}{ P5 } & $1987-2013$ & 295 & $100-200$ & 190.52 & Subsidence [m] & -1.6 & -0.3 & 0 & -1.9 \\
\hline & & & & & Rate $[\mathrm{cm} / \mathrm{yr}]$ & -10.6 & -9.9 & -6.7 & - \\
\hline
\end{tabular}

\footnotetext{
*Due to the lack of piezometric measures from 1987 to 2003 , the reported water level variation values cover the 2003-2007 time interval and as a consequence the entire water level variation start from the same date.
} 


\section{Figure}

Click here to download Figure: Figures.docx
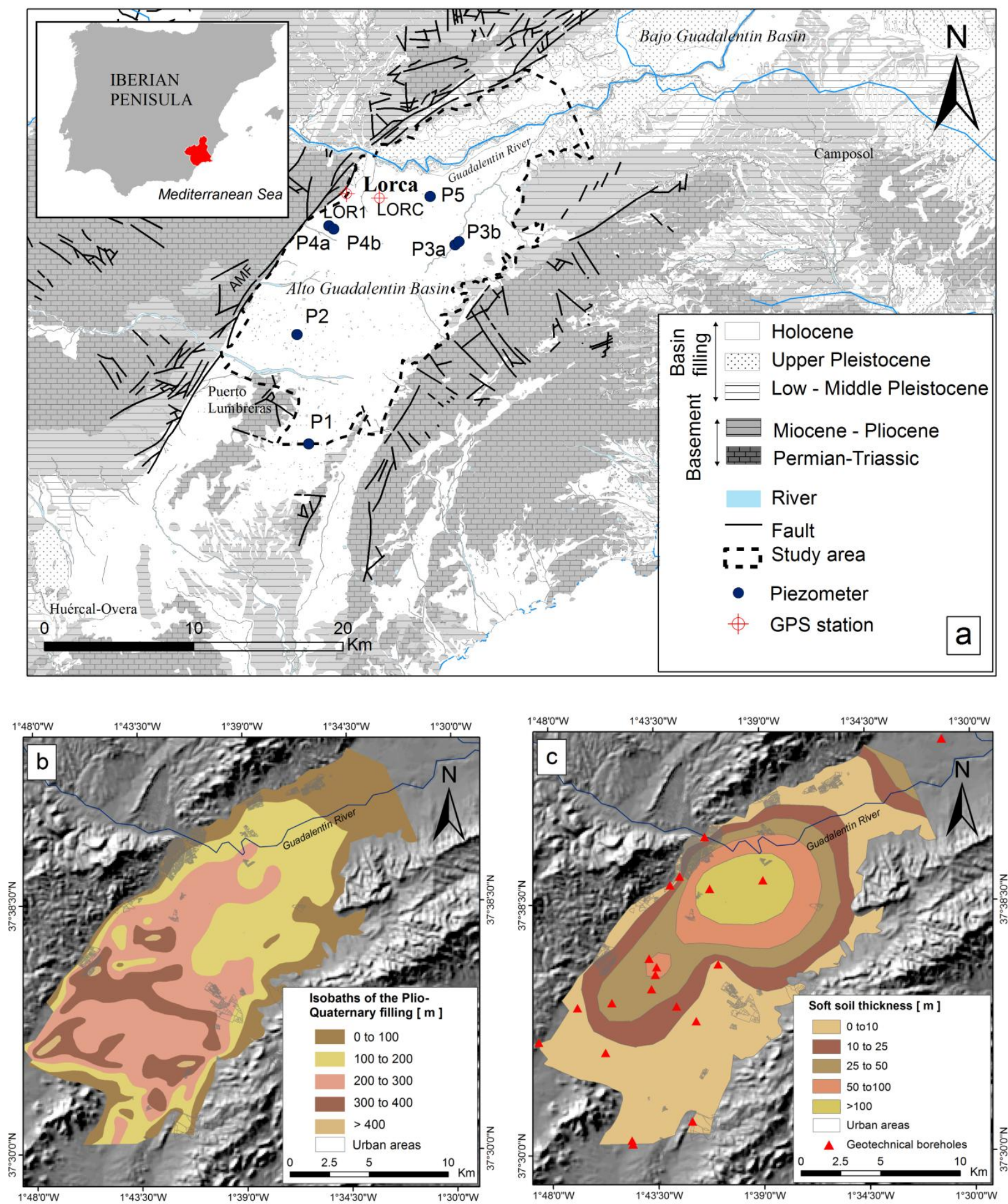

Figure 1. 

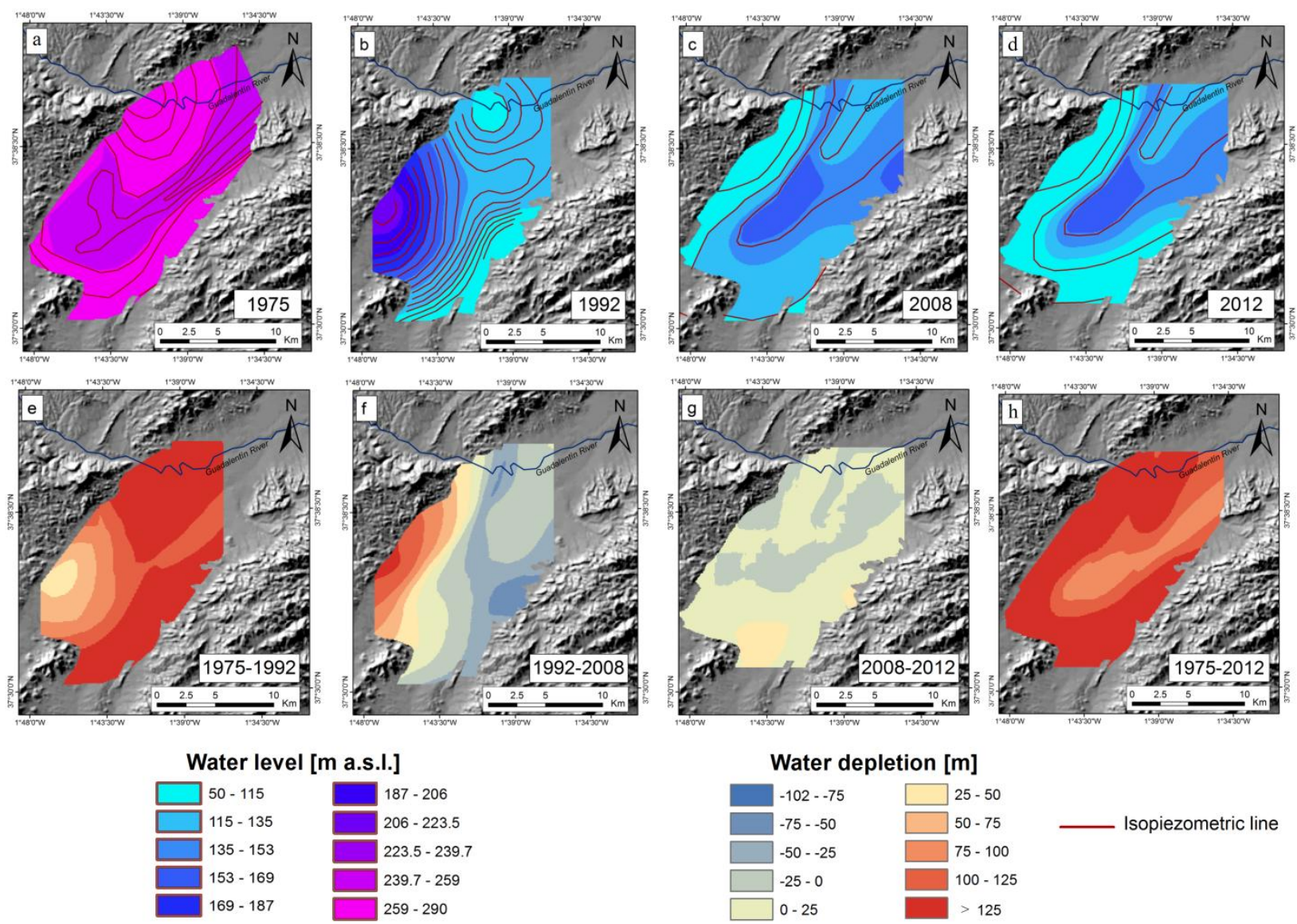

Water depletion [m]
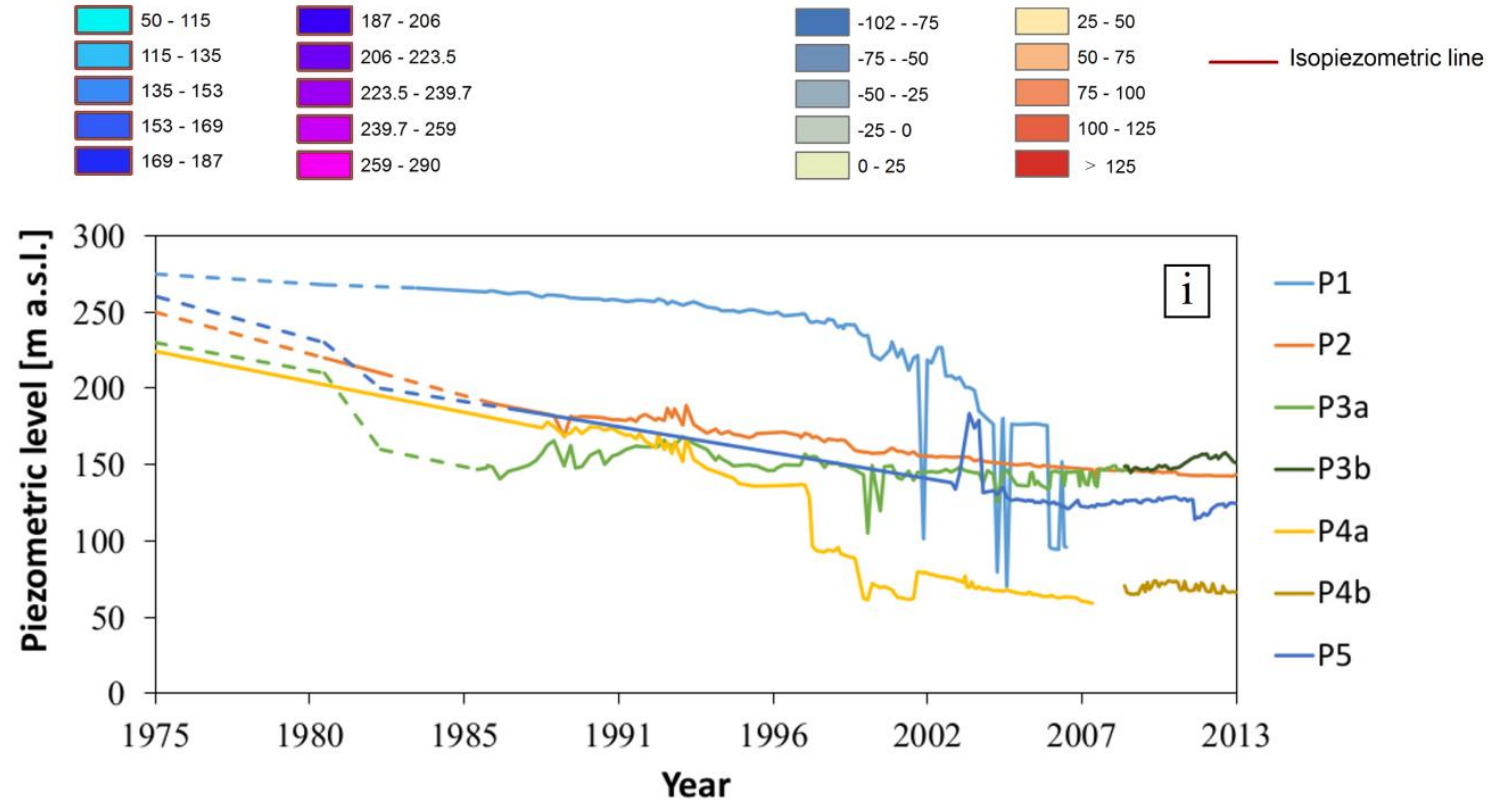

Figure 2. 

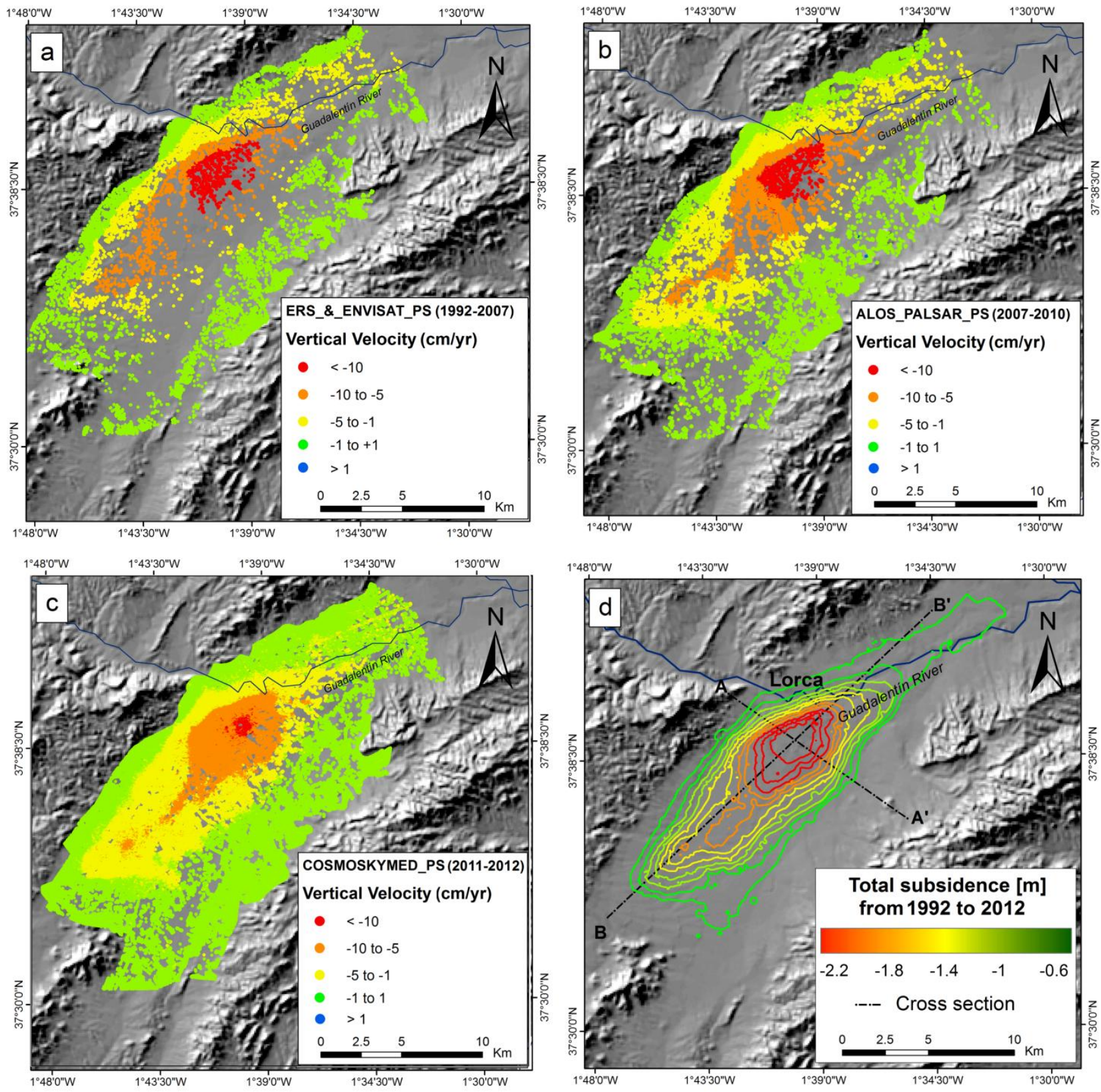

Figure 3. 

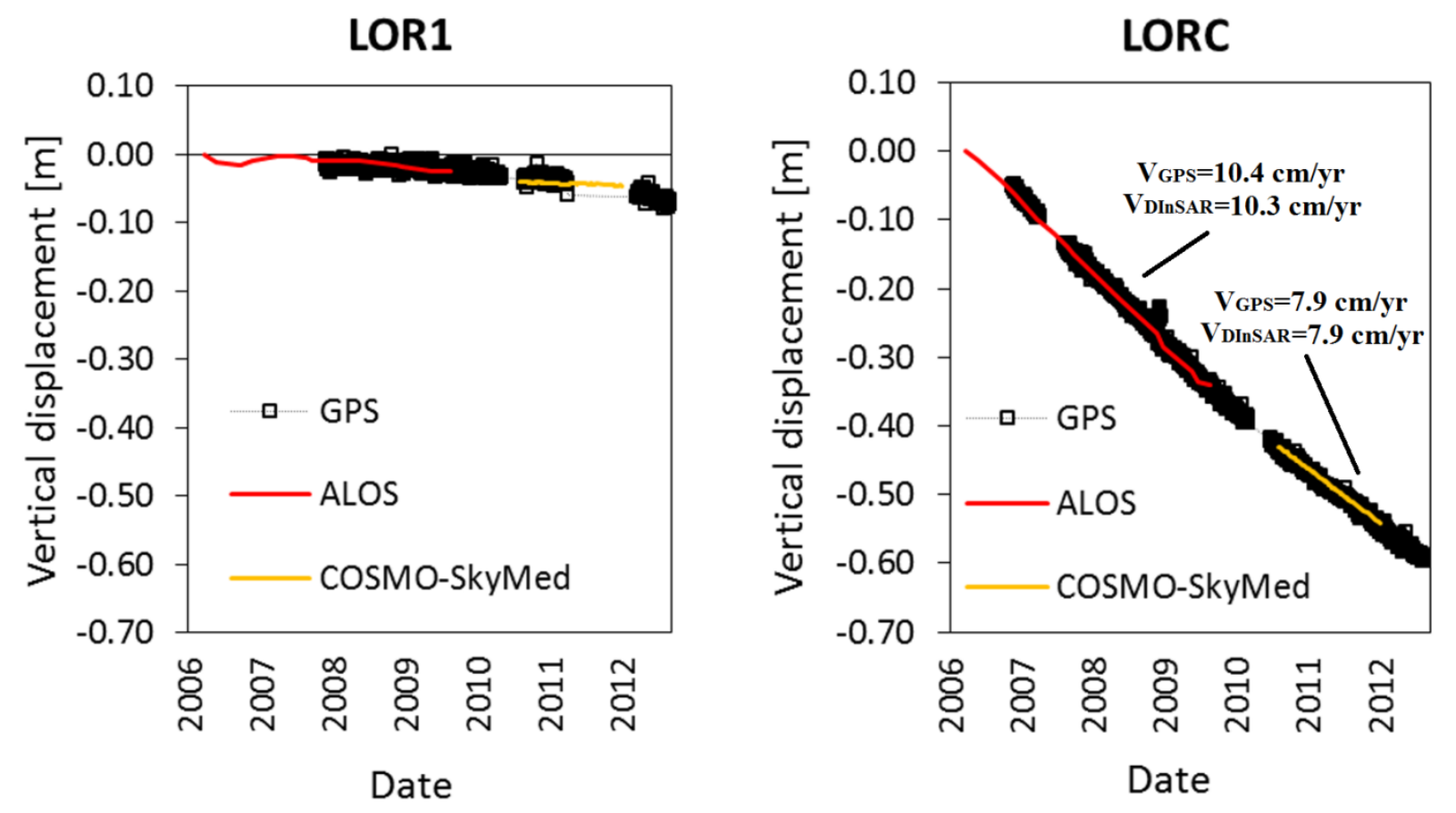

Figure 4. 

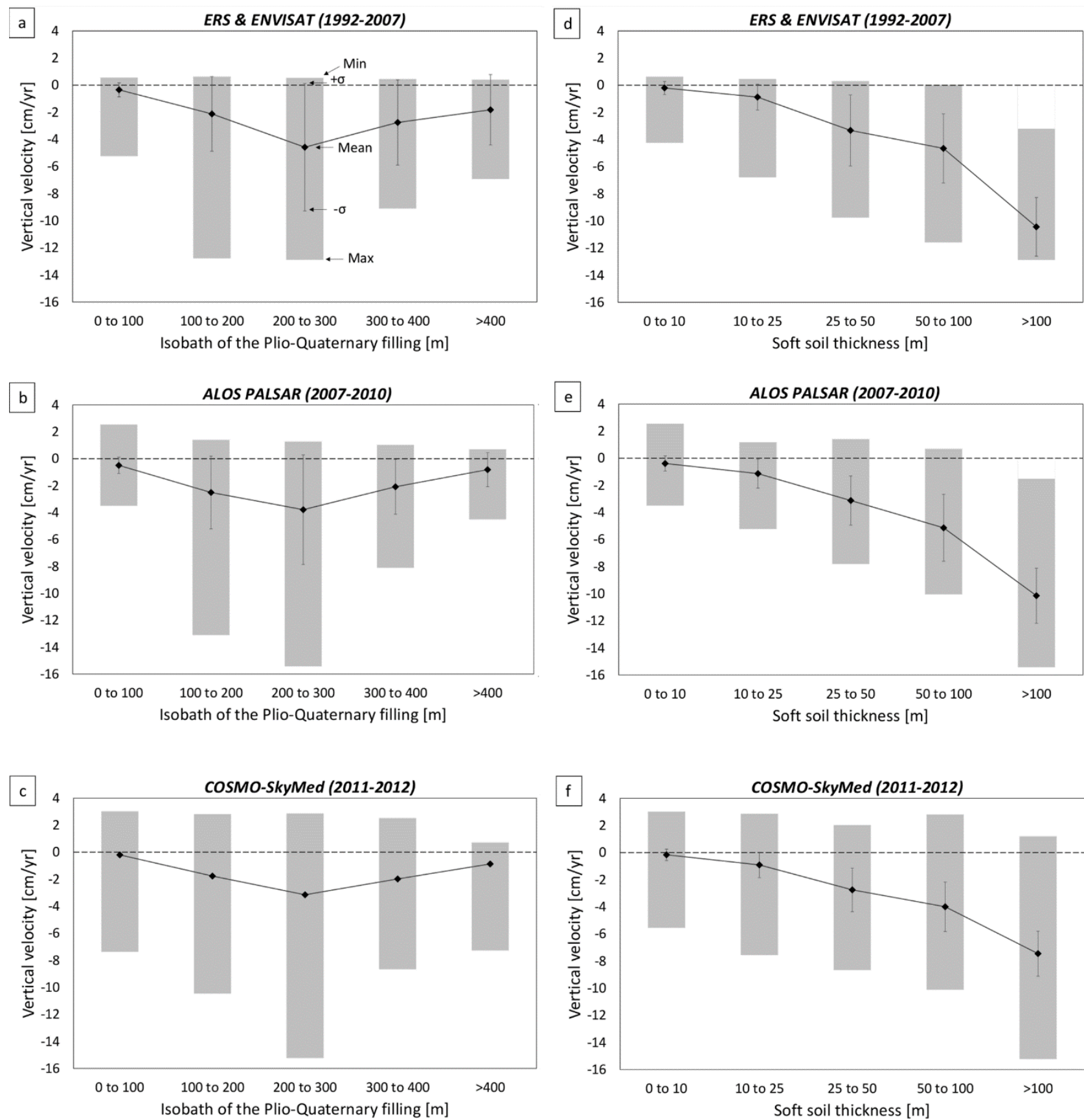

Figure 5. 

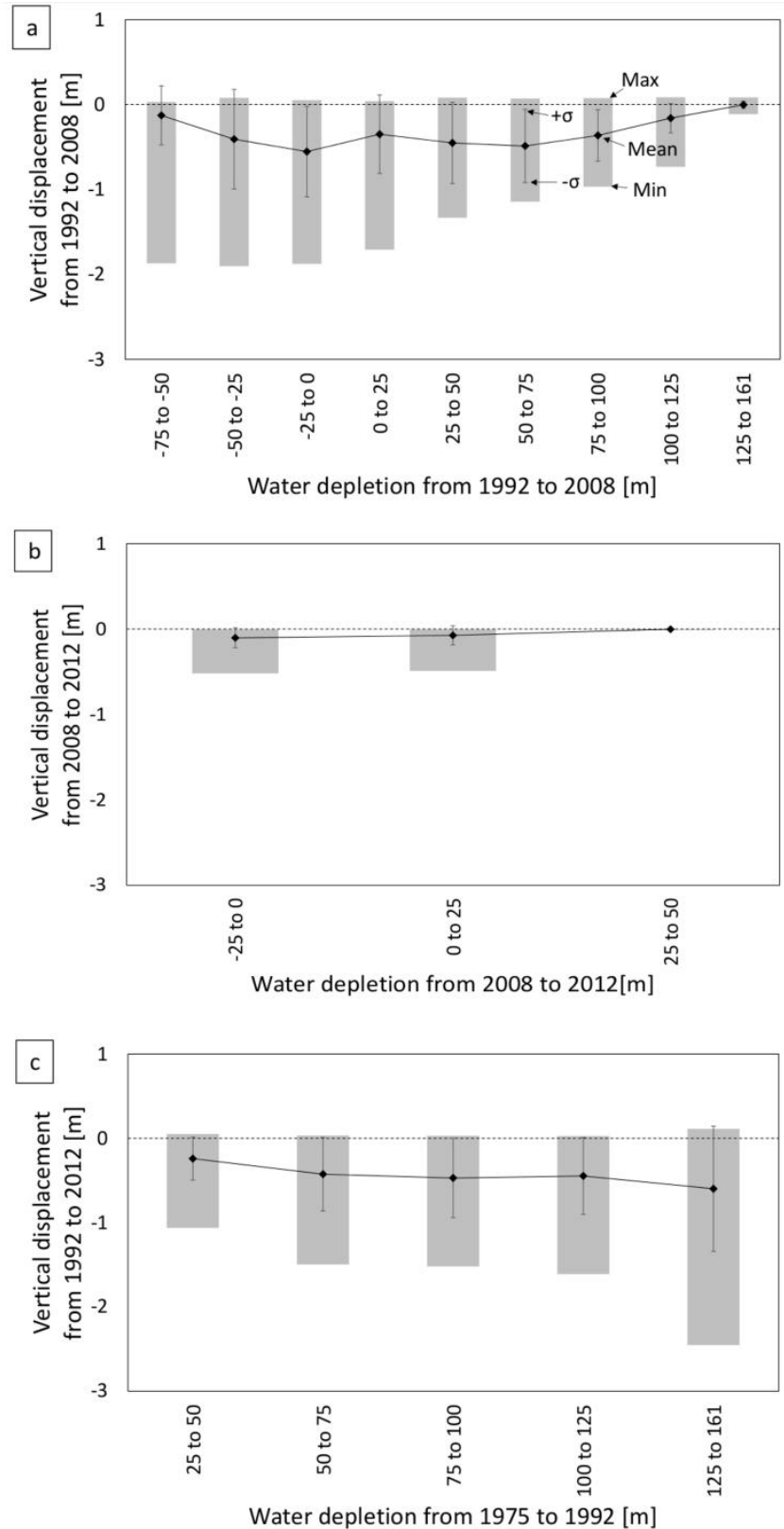

Figure 6. 

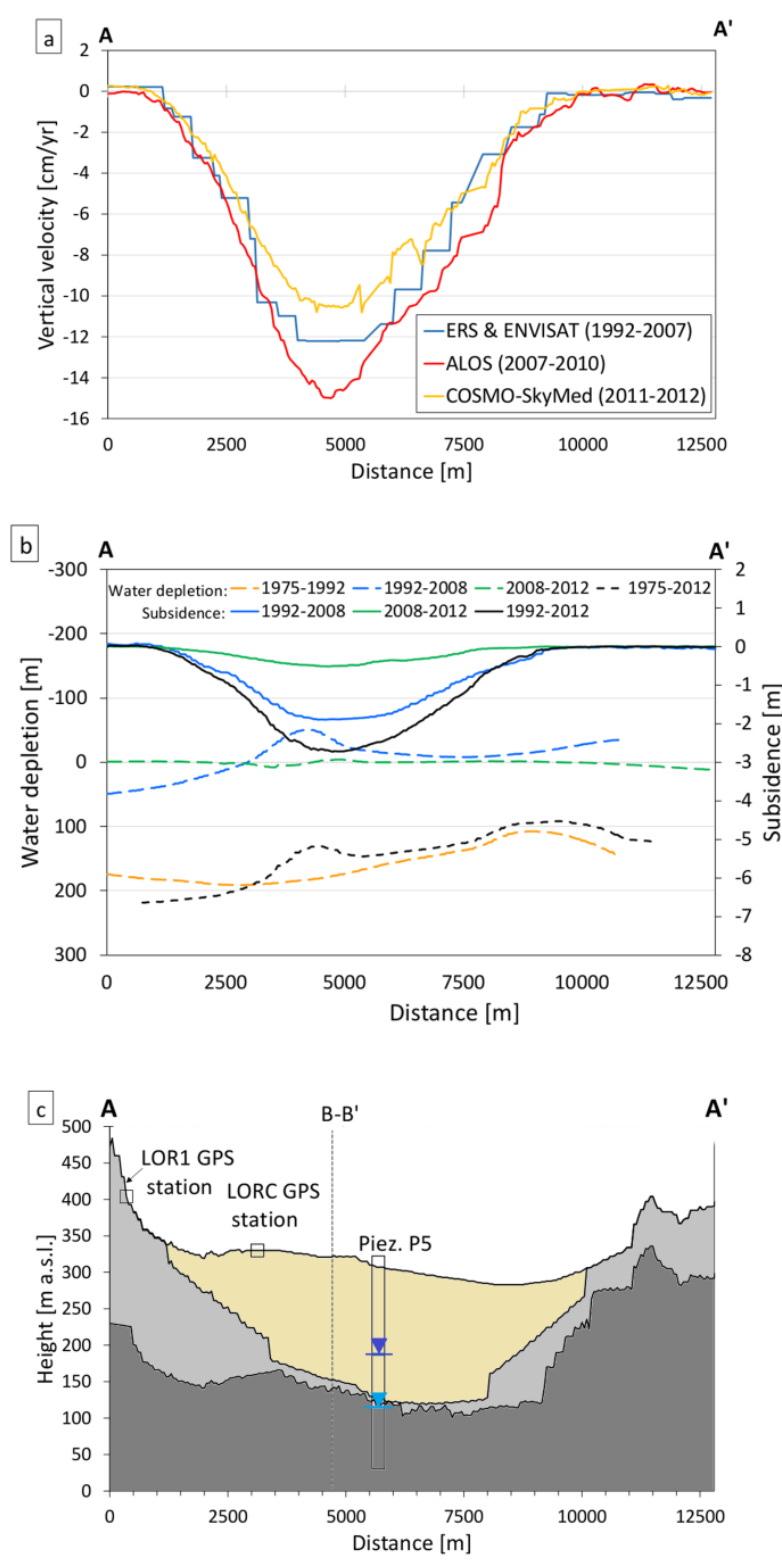

Compressible soil
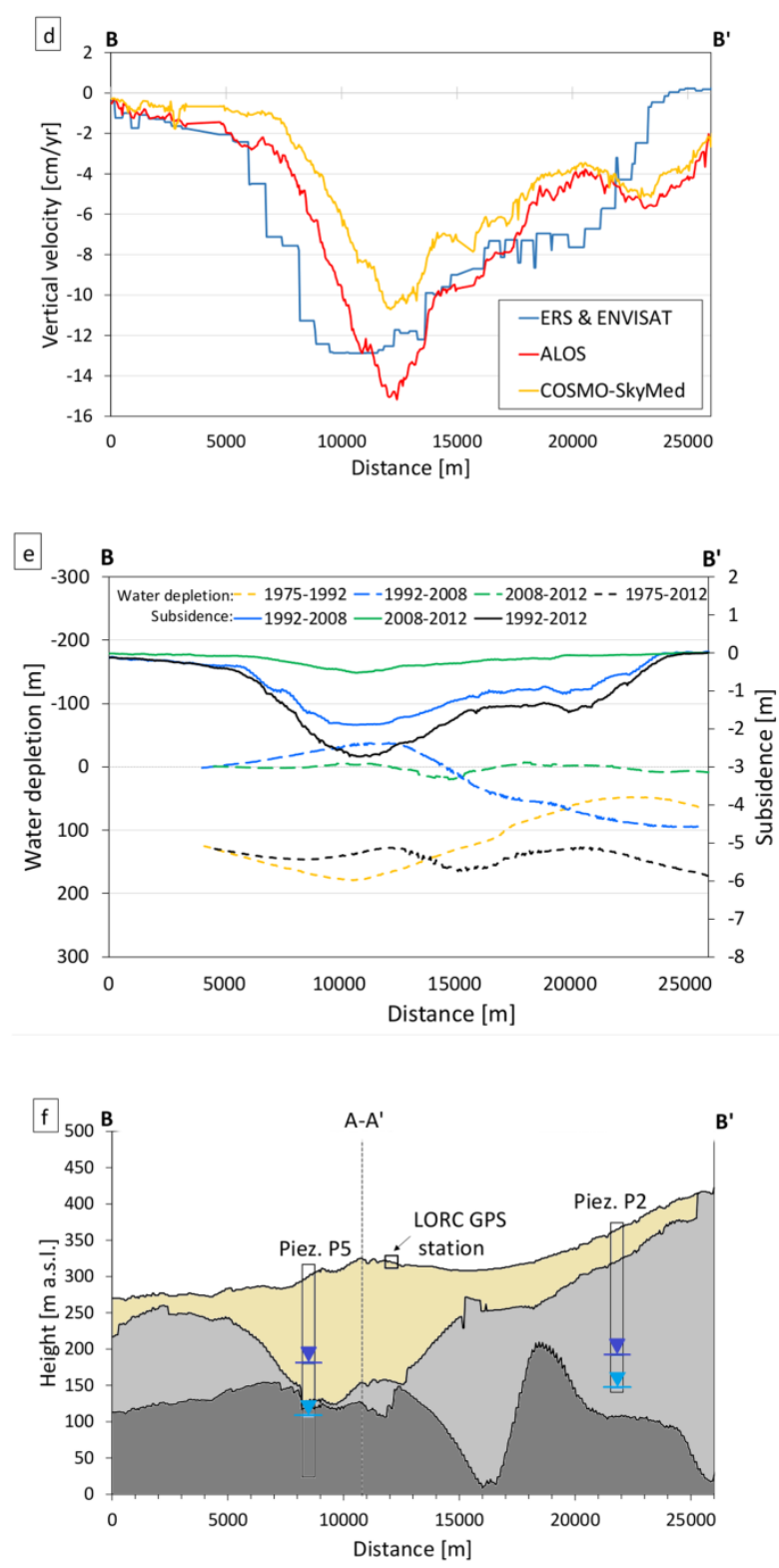

Plio-Quaternary substratum

$\nabla$ Maximum piezometric level $\quad \square$ Minimum piezometric level

\section{Figure 7.}



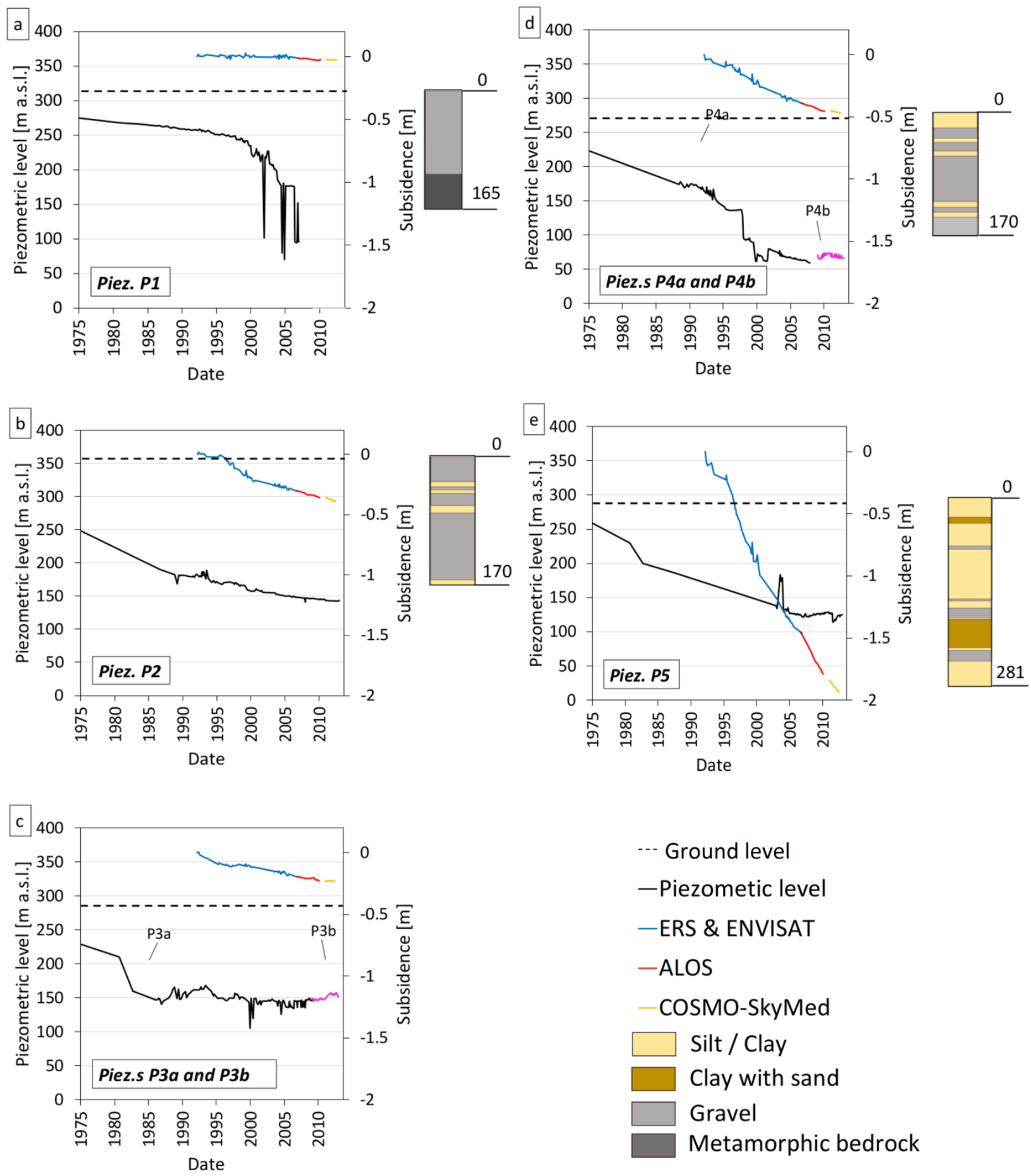

-- Ground leve

-Piezometic level

-ERS \& ENVISAT

- ALOS

- COSMO-SkyMed

Silt / Clay

Clay with sand

Gravel

Metamorphic bedrock

Figure 8. 


\section{Figure captions:}

Figure 1. (a) Geological setting of the Guadalentín Basin (redrawn from Martín et al., 1972); piezometers and GPS sites used in this study area are also reported. (b) Plio-quaternary filling (based on Cerón and Pulido-Bosch, 1996). (c) Compressible thickness map and geotechnical boreholes location. The thickness of the compressible deposits has been calculated by means of geotechnical boreholes data. (For the interpretation of the compressible thickness map, the reader is referred to the paragraph 4.1 in the maintext). Urban areas are also reported in panels $\mathrm{b}$ and $\mathrm{c}$.

Figure 2. Maps of the water level [m a.s.1.] in 1975 (a) and 1992 (b), derived from Cerón (1995, 1999); in 2008 (c) and 2012 (d) from Confederación Hidrográfica del Segura (CHS, 2014). Piezometric drawdown from 1975 to 1992 (e), from 1992 to 2008 (f), from 2008 to 2012 (g) and from 1975 to 2012 (h). Note that positive values represent drawdown of the water level and the negative values are recovery of the water level. (i) Time series of seven piezometers from 1975 to 2013. The dotted lines represent measures obtained from Cerón (1995). See the location of the piezometers in Figure 1a.

Figure 3. Vertical velocity maps for the 1992-2007 period (obtained using data from ERS and ENVISAT satellites) (a), for the 2007-2010 period (ALOS PALSAR satellite) (b) and for the 2011-2012 period (COSMO-SkyMed satellites) (c). Cumulated displacements (m) of the Alto Guadalentín Basin from 1992 to 2012. Locations of the cross sections A-A' and B-B', plotted in Figure 7, are marked in panel (d).

Figure 4. Comparison between the DInSAR and GPS vertical displacements time series. See Figure 1a for the GPS stations location. At the LORC time series has been reported the vertical velocity rate $[\mathrm{cm} / \mathrm{yr}$ ] detected in the period 2007-2010 and 2011-2012 by the GPS and DInSAR measurements. 
Figure 5. (a) Relationship between the isobaths of the Plio-Quaternary filling (Cerón and PulidoBosch, 1996) and the vertical velocity [cm/yr] valued for the ERS \& ENVISAT dataset. The same for (b) the ALOS dataset and (c) for the COSMO-SkyMed dataset. See the Plio-Quaternary filling map in Figure 1b. Relationship between the soft soil thickness and the vertical deformation rates for the three dataset are shown in panels (d), (e) and (f) respectively. See compressible thickness map in Figure 1c. The maximum, minimum, mean (black dots) and the standard deviation of the average values of deformation rates are represented.

Figure 6. (a) Comparison of the vertical displacements [m] with the water depletion $[\mathrm{m}]$ detected in the period 1992-2008, (b) and 2008-2012. (c) Comparison of the total displacements from 1992 to 2012, with the water depletion from 1975 to 1992.

Figure 7. Profile of the deformation rates of multi sensor data (a), (d); and comparison of the vertical displacements with the water depletion (dotted lines) along the A-A' (b) and B-B' (e) profiles. The geological cross sections are shown in panels (c) and (f) respectively. See the location of the cross sections in Figure 3d. The maximum and minimum piezometric level stand for the maximum and minimum water level recorded at the piezometer. GPS stations locations are also reported (square symbols).

Figure 8. Comparison of the water level variations from 1975 to 2012 (black and pink line) at the different piezometers (P1, P2, P3a, P3b, P4a, P4b, and P5) located on Figure1a, and the vertical displacements detected by the satellite sensors (blue, red and yellow lines). In addition for some piezometers it is represented the lithological column. The dotted line is the ground level. Piez. stands for piezometer. 